The successor to the journal Music Review, Nineteenth-Century Music Review aims to locate music within the widest possible framework of intellectual activity pertaining to the long nineteenth century (c.1789-1914). It particularly welcomes interdisciplinary scholarship that explores music within the context of other artistic and scientific discourses. Articles with fine visual or iconographic content are encouraged, as are those rich in musically illustrative material. Articles accepted for publication will reflect a diversity of critical viewpoints.

\title{
Contents of Volume 6, Issue 2
}

Articles

Emma Sutton

Rosemary Golding

Andrew H. Weaver

E. Douglas Bomberger

Peter Dayan

Review Article

Heather Platt
Too Close for Comfort: Henry James, Richard Wagner and The Sacred Fount

Musical Chairs: The Construction of 'Music' in NineteenthCentury British Universities

Poetry, Music, and Fremdartigkeit in Robert Schumann's Hans Christian Andersen Songs, op. 40

Putting Words in the Master's Mouth: Anton Strelezki's Personal Recollections of Chats with Liszt

Truth in Art, and Erik Satie's Judgement

New Paths to Understanding Brahms's Music: Recent Analytic Studies

Book Reviews

CD Reviews

Letter to the Editor

Marcia J. Citron

Coda: A Reply to Marian Wilson Kimber

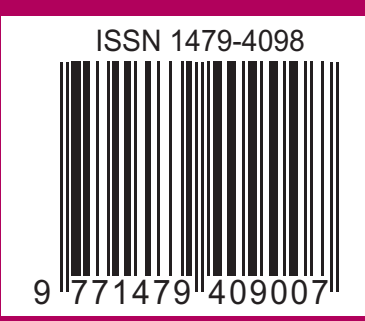

